\title{
A COMPARISON OF EVENT IMPACTS: ZIMBABWE AND THE UK
}

\author{
DEBORAH SADD AND RUTENDO MUSIKAVANHU
}

Department of Events and Leisure, Faculty of Management, Bournemouth University, Poole, UK

\begin{abstract}
The study explores negative and positive impacts of events in both developing and developed nations. Using Zimbabwe and the UK as examples, the aim is to demonstrate the different ways event impacts affect different societies. The main finding was the discovery of a gap in existing event studies, clarifying that there are limited frameworks that are intended to gauge the scope of event impacts within emerging nations. In addition to this, events can result in negative and positive impacts and these are determined by the implementation of the event. This is fundamentally subjective to social, political, and economic impacts within the community, thus again questioning the literature in relation to developing nations.
\end{abstract}

Key words: Event management; Impacts; Developing nations; Zimbabwe

Introduction

Event studies have grown significantly since the beginning of the 21st century (Jago, Dwyer, Lipman, van Lill \& Vorster, 2010; Quinn, 2009). Events vary from mega-events to community festivals and so, therefore, do the associated impacts (Jago \& Dwyer, 2006). For instance; the Olympic Games, FIFA World Cup, and Rugby World Cup are mega in complexity, scale, and impacts compared to smaller events like the European City of Culture or Tour de France. Contemporary event studies have conventionally been conducted in developed nations overlooking the significance of research in developing nations that are now experiencing a surge of mega-events being hosted in their regions.

Studies from developed nations produce results that reflect on their political structures, economic security, and social welfare and are expectedly different from those of developing countries, therefore questioning the correlation of existing research to events emerging from developing countries. Nevertheless, a handful of scholars such as Cornelissen (2004), Foley, McGillivray, and McPherson (2012), Saayman (2012), and Swart and Bob (2007, 2012) have shifted the focus to studying events in developing countries. This research will focus on the overlapping themes of economic, sociocultural, and political impacts providing important indicators of evaluating event impacts in developed nations (UK) compared to developing nations using Zimbabwe as the case study.

The aim of this research is to critically analyze the event impacts between a developed and a developing destination to demonstrate the different event impacts and consequences. 


\section{Emerging Event Destinations}

China used the 2008 Olympic Games to capitalize on the shift in global power, using the Games to change international opinion in a country shrouded by negative international perception, paving the way for other developing nations (Nye, 2004). The bid presented to the international community showcased China's culture, strength, and resources, in turn gaining approval and international trade benefits. This was an exemplary move of using an event to change perceptions and showcase their resources. South Africa similarly embarked on several event proposals in a bid to change the perception of the country and the continent at large (AT Kearney, 2005) using the 1995 Rugby World Cup and FIFA 2010 World Cup as tools to gain traction on the international event platform for the nation and continent (Shipway \& Fyall, 2012).

Prior to these endeavors, the field of events had been dominated by Western nations. Australia has been home to many successful events such as the Classic Adelaide Car Rally, Sensational Adelaide Tour Down Under, and the Sydney 2000 Olympics
(Pomfret, Wilson, \& Lobmayr, 2009). Although, Edmonton in Canada attributes its event accomplishments to community-centered volunteer schemes that effectively lowered event operational costs and increasing profit margins benefiting the community (Nessel, 2009). Table 1 offers examples of successful events hosted by developed nations that served to cement these nations as event frontrunners (HM Government, 2013; Olympic.Org, 2012).

These outcomes have raised interest within developing nations that have recognized the potential of community development through harnessing event resources. These developing nations are grouped in to three: (1) MENA: Middle East and North Africa; (2) BRICS: Brazil, Russia, India, China, and South Africa; (3) CIVETS: Colombia. Indonesia, Vietnam, Egypt, and Turkey (Joy, 2013).

However, developing regions often have tendencies to attract social and economic problems (Sloman, 2006). For instance, during the 2010 Angolan Africa Cup of Nations, a bus carrying Togo's national football team was set on fire resulting in extensive negative attention; similarly, in Pakistan, attacks on cricketers caused the country

Table 1

Successful Events from Developed Nations

\begin{tabular}{|c|c|}
\hline Location/Event & Impact \\
\hline \multicolumn{2}{|l|}{ England } \\
\hline Glastonbury Festival & Worldwide economic impact of $£ 73$ million in 2007 \\
\hline \multicolumn{2}{|r|}{ 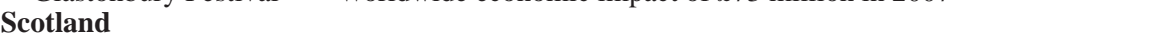 } \\
\hline $\mathrm{T}$ in the Park Festival & $£ 40$ million in 2011 up from $£ 18$ million in 2005 \\
\hline \multicolumn{2}{|l|}{ Great Britain } \\
\hline \multirow[t]{6}{*}{ London Olympics } & $74 \%$ of the British people would welcome the Games back \\
\hline & Games resulted in $11 \%$ increase in physically active British people \\
\hline & $£ 9.9$ bn increase in business and investment from the Games \\
\hline & 22\% people believed local economy improved \\
\hline & 21\% people believed local public services had improved \\
\hline & 32\% people felt the Games left behind a lasting legacy \\
\hline \multicolumn{2}{|r|}{ 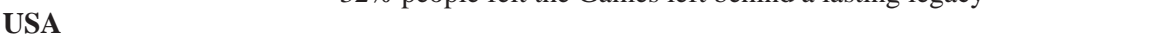 } \\
\hline \multirow[t]{4}{*}{ Super Bowl } & Has produced invaluable advertisement \\
\hline & Has enhanced reputation of each destination \\
\hline & Has proven profitable to all host destinations \\
\hline & Is the most watched sporting event in USA \\
\hline \multicolumn{2}{|r|}{ 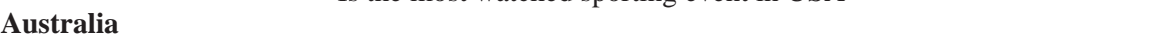 } \\
\hline \multirow[t]{4}{*}{ Sydney Olympics } & $\begin{array}{l}\text { Paved the way for other world-class events: Rugby World Cup \& the } \\
\text { World Masters Games }\end{array}$ \\
\hline & $\begin{array}{l}\text { The Olympic Park is now a flourishing commercial \& residential area, } \\
\text { home to } 130+\text { organizations, providing } 12,000 \text { jobs }\end{array}$ \\
\hline & An average of 6,000 events/year are hosted at the Olympic Park \\
\hline & Events hosted in the Park generates an average of AU\$1 billion \\
\hline
\end{tabular}

Source: Adapted from Bond (2013); Kahane and Shmanske (2012); Moore (2012); and Olympic. Org (2012). 
to be barred as a future host (Jago et al., 2010). India experienced problems with the 2010 Commonwealth Games as athletes complained about the lack of security, inadequate technology, and unclean facilities (MacIntosh \& Nicol, 2012). Nevertheless, these issues have not limited developing nations from seeking to become successful host nations. Table 2 identifies developing nations that have hosted or are due to host mega-events, a first-time experience for most of the developing countries with the subsequent impacts.

\section{The Challenge of Hosting Events}

Events are known to transform communities as exemplified by the Barcelona 1992 Olympics whereby Barcelona became a dynamic European destination shifting unemployment numbers from 18.4\% to 9.6\% (Brunet, 2005; A. Smith \& Fox, 2007). Hosting events in developing countries is a multifaceted responsibility that requires defying misconceptions and stereotypes, thus increasing the pressure to deliver successful events on the same level as the developed nations (MacIntosh \& Nicol, 2012; Preuss \& Alfs, 2011). When bidding for events, most developing nations are disadvantaged because they do not naturally have matching funds, skills base, and infrastructural capacity as seen in developed nations (Saayman, 2012). However, any event can result in negative impacts and this outcome is not only confined to developing nations. The Athens 2004 Olympics resulted in financing problems from a developed nation generating negative impacts, as even a decade later the infrastructure is redundant despite the city having intended a praiseworthy legacy (H. Smith, 2012). Malpractice led to financial wastage during the Sochi 2014 Winter Olympics, initially proposing a
$\$ 12$ billion budget but instead investing a record $\$ 50$ billion (Yaffa, 2014).

In contrast, the UK has effectively hosted several mega-events (Table 3) serving to solidify their leading role within the industry worldwide. Manchester underwent restoration as a result of the 2002 Commonwealth Games with the successful reuse of several venues such as the City of Manchester Stadium (Hetherington, 2012). London 2012 cost over £9.9 billion and London's Olympic Stadium has been home to The Anniversary Games, hosting several Rugby World Cup 2015 matches, and will eventually host the West Ham Football Club move in by 2016 (Flanders, 2013; Nash, 2013).

\section{Characteristics of Emerging Nations Versus Established Nations}

The BRICS have recently assumed the role of development agents for other developing countries, an interesting move considering many African economic and political structures were designed after their former European colonies (United Nations, 2010). In 2009 the BRICS posted a combined 15\% of global GDP and are expected to have amassed $25 \%$ by the end of the decade (Horne, 2010; Joy 2013) while the Eurozone continues to struggle (Wearden, 2014). India and China embarked on helping Guyana, Grenada, Jamaica, and Antigua with preparations for the 2007 West Indies ICC Cricket World Cup (Horne, 2010). Equally, Russia developed a foreign aid budget, contributing \$472.32 million in 2010 to developing nations (Provost, 2011); likewise, Brazil funded $\$ 1.6$ billion in foreign aid between 2005 and 2009 (Hochstetler, 2012). China and Brazil reached out to Ethiopia, Ghana, Mozambique, and Zimbabwe, assisting with development projects (Mukwereza, 2013) enabling

Table 2

Emerging Event Destinations

\begin{tabular}{|c|c|c|c|c|c|}
\hline China & South Africa & India & Brazil & Russia & Qatar \\
\hline 2008 Olympics & $\begin{array}{l}2010 \text { FIFA World Cup } \\
\text { Bidding for } 2022 \\
\text { Commonwealth } \\
\text { Games }\end{array}$ & $\begin{array}{l}2010 \text { Commonwealth } \\
\text { Games }\end{array}$ & $\begin{array}{l}2014 \text { FIFA World } \\
\text { Cup } \\
2016 \text { Olympic } \\
\text { Games }\end{array}$ & $\begin{array}{l}2014 \text { Winter } \\
\text { Olympics } \\
2018 \text { FIFA } \\
\text { World Cup }\end{array}$ & $\begin{array}{l}2022 \text { FIFA } \\
\text { World Cup }\end{array}$ \\
\hline
\end{tabular}

Source: Foley et al. (2012); Beaumont and Fraser (2014). 
Table 3

\begin{tabular}{ll} 
UK Mega-Events \\
\hline Year & \\
\hline 1948 & London Olympic games \\
1966 & FIFA World Cup (UK) \\
1979 & Cricket World Cup (UK) \\
1983 & Cricket World Cup (UK) \\
1991 & Rugby Union World Cup (England, Scotland, Wales, Ireland and France); Sheffield World Student Games \\
1996 & UEFA Football Championships (UK) \\
1999 & Rugby Union World Cup (Wales); Cricket World Cup (Scotland, Ireland, Wales, and the Netherlands) \\
2000 & Rugby League World Cup (Great Britain, Ireland and France) \\
2002 & Ryder Cup (UK); Manchester Commonwealth Games \\
2003 & Birmingham World Indoor Athletics Championships \\
2010 & Ryder Cup (Wales); Women’s Rugby World Cup (UK) \\
2012 & London Olympic Games \\
2014 & Glasgow Commonwealth Games
\end{tabular}

Source: Adapted from Bowdin et al. (2012).

Zimbabwe to host the United Nations World Tourism Organization (UNWTO) Conference, gaining the title of "The World Tourist Destination of the Year 2014” (Mudzaki, 2014). Additionally, Zimbabwe is establishing an event base as illustrated in Table 4.

Events generate both positive and negative legacies; therefore, measuring the success of an event should include positive and negative impact assessments. Society will pursue benefits such as infrastructure development and financial gain from events in exchange for their resources. The Manchester 2002 Commonwealth Games in conjunction with the Commonwealth Games Opportunities and Legacy Partnership Board resulted in a $4 \%$ increase in long-term and short-term jobs, construction of an Asda-Walmart superstore, refurbishment of the Manchester Stadium, and the English Institute of Sport is now a training site-all generating income and serving as a longstanding legacy (Gratton \& Preuss, 2008). Justifying the premise of the social exchange theory, founded on the idea that exchanges are codependent, communities are prepared to endure associated social disruptions in order to achieve community regeneration or in return for other social, economic, and political benefits (Jackson, 2008). London 2012 effectively converted event infrastructure to benefit the public and Los Angeles 1984 Olympics reused previous infrastructure (Saayman \& Saayman, 2012).

Governments are becoming more visible within the organization of events, providing economic assistance, driving cultural and national beliefs (Jago \& Dwyer, 2006; Jago et al., 2010). The FIFA 2010 World Cup was an opportunity to drive poverty relief and funding for the 54 African states that have often been negatively type casted (Shipway \& Fyall, 2012). Various countries have established unions whose responsibility is to host sought-after events, for instance the Victorian Major Events Company (VMEC Australia), The Indiana Sports Commission, and Central Florida Sports Commission of the USA (Hede, 2008). The UK has Event Britain, EventWales, and EventScotland, organizing community events such as the Queen's Golden Jubilee Celebrations of 2002, serving to unite communities in a celebration of national culture and pride (Bowdoin, Allen, O’Toole, Harris, \& McDonnell, 2012; Davies, 2011; O’Toole, 2011). This confirms that governments are now recognizing the way in which events have become a facilitator of development.

Table 4

Events Hosted in Zimbabwe

1. The Harare International Festival of Arts (HIFA)

2. The Bulawayo Music Festival

3. The Chimanimani Arts Festival

4. The Victoria Falls Carnival and Color Run

5. The Victoria Falls Marathon

6. The Victoria Falls Mountain Bike Challenge

Source: Adapted from Murray (2013); Zimbabwe Tourism (2014). 


\section{Sociocultural Frameworks}

The growth of the events market has resulted in the need for a robust appraisal of events, consisting of comprehensive postevent assessment and thorough interpretation of the associated impacts. The Kwazulu Natal Sport and Recreation Department, through AT Kearney (2005), proposed a development model that consists of three stages: emerging, evolving, and excellent, as identified in Figure 1. The model proposes that a country will go through three stages of development, growing out of poor governing policies and poor quality of life and developing into a stable society with the eventual acclimatization into a nation with a vibrant economy, effective government, and high standards of living (AT Kearney, 2005).

It is understood that as the host community's attitude towards the developments becomes more noticeable, variances such as cultural differences and socioeconomic status between the host community and the visitors becomes more visible and obstinate (Trauer \& Ryan, 2005). The Doxey Irritation Index (Irridex) (Doxey, 1975) is a recognized framework of changing visitor/host relations mainly in the context of tourism (Latkova, 2008), but it has been adapted here to facilitate an understanding of how event impacts could also affect communities. Figure 2 illustrates the progression from "euphoria, to apathy, to annoyance and finally to antagonism" because residents blame visitors for the negative impacts brought to their community. The final level of antagonism is realized once the host community has reached its saturation level, explaining the community's changing approach concerning visitors rendering to the experienced negative feelings of irritability that develop as events continue to grow in their community (Monterrubio Cordero, 2008).

The act of the host community obtaining the "value" they require from the visitors by offering commensurate services in return, is considered to be a social exchange where expenses incurred from hosting an event are equal to the benefits (Murphy \& Murphy, 2004). The social exchange theory proposes that the relationship between the residents and the visitor depends on costs versus benefits (Fig. 3) where both parties have great levels of influence and power within the relationship, originating from having control and influence over resources that one of the party requires and finds to be of value (Hardcastle, 2011). In 1992, Ap adapted this theory to tourism, which has therefore been applied to this events study. The cost of interaction between the host community and visitors should be worth the investment made and this is measured by assessing the benefits and whether the community sees these results as positive or negative (Kirst-Ashman, 2013). However, these benefits can only be anticipated as contributions to the exchange are made in real time, making it a relationship that relies on each party fulfilling their obligations.

\section{Research Methodology}

The research adopted a qualitative descriptive method using semistructured interviews that asked direct questions to fulfill the research objectives (Sandelowski, 2000). This is a method that relies on a trust-based relationship, with the participants accurately describing the order of events for validity purposes (Corbin \& Strauss, 2008), thus creating an opportunity for the researcher to empathize and identify. Therefore, this is very important in that the researcher can avoid subjectivity and not misleading the interpretation process. Ethical considerations were important as the method examined private lives and shared these accounts with the public.

A total of 14 respondents - 8 from Zimbabwe and 6 from the UK-were selected based on their industry experience as key informants, for the purpose of comparing and contrasting a developing and developed country as per the research question. The respondents were purposively chosen for the specific role within the events industry they hold or in a role that impacts upon the events industry in their own country. It was hoped to mirror across the two examples as much as possible, but this was not feasible due to different country and event structures. Although it appears that the respondents are diverse, it was not possible to match like for like roles because of national differences. However, it is their role with the events industry that forms an important addition to this research in comparing across a developed and developing nation. Existing networks were used both in the UK and Zimbabwe, based on one of the authors work experience, and also snowballing to gain additional respondents. 


\begin{tabular}{|c|c|c|c|}
\hline & Emerging & Evolving & Excellent \\
\hline $\begin{array}{l}\text { Social, cultural } \\
\text { and } \\
\text { environmental }\end{array}$ & $\begin{array}{l}\text { Weak social fabric, ethnic } \\
\text { divisions, and limited civil } \\
\text { society or community } \\
\text { participation } \\
\text { Poor quality of life, lack of } \\
\text { public support for arts and weak } \\
\text { environmental standards } \\
\text { Health-care and education are } \\
\text { poorly funded } \\
\text { Limited access to loans and } \\
\text { housing }\end{array}$ & $\begin{array}{l}\text { Stable and tolerant society } \\
\text { with supportive institutions } \\
\text { Environmental degradation in } \\
\text { urban centres; limited cultural } \\
\text { and leisure lifestyle } \\
\text { Health-care and education are } \\
\text { government priorities but } \\
\text { mismanagement and } \\
\text { bureaucracy hamper results } \\
\text { Sanitation services in place } \\
\text { but access to clean air, water } \\
\text { and health is limited }\end{array}$ & $\begin{array}{l}\text { Diverse, tolerant society with } \\
\text { wide choice of lifestyles, leisure } \\
\text { and cultural activities } \\
\text { Focus on urban and community } \\
\text { design that fosters public health, } \\
\text { well-being, business growth and } \\
\text { efficient use of resources } \\
\text { High quality education and } \\
\text { health-care available to all } \\
\text { Public sanitation is efficient and } \\
\text { provided at low cost; leading } \\
\text { environmental standards }\end{array}$ \\
\hline Economics & $\begin{array}{l}\text { Basic educational system with } \\
\text { limited links to business or } \\
\text { academic communities } \\
\text { Industry driven by a few } \\
\text { vertically } \\
\text { integrated sectors, poor supply } \\
\text { chains, import-dependent and } \\
\text { limited service sector } \\
\text { Central bank is not independent } \\
\text { and subject to investor } \\
\text { uncertainty } \\
\text { Poor fiscal management, } \\
\text { inflation, } \\
\text { high debt levels, volatile } \\
\text { financial } \\
\text { markets and weak growth }\end{array}$ & $\begin{array}{l}\text { Science and technical } \\
\text { institutions support industry } \\
\text { and are wired into overseas } \\
\text { knowledge centres } \\
\text { Moderate levels of } \\
\text { productivity, yet weak in } \\
\text { terms of innovation } \\
\text { Moderate to strong growth, } \\
\text { though not sustainable; } \\
\text { economy still vulnerable to } \\
\text { swings } \\
\text { Sound economic policies help } \\
\text { build investor confidence, but } \\
\text { political transitions can upset } \\
\text { markets }\end{array}$ & $\begin{array}{l}\text { Vibrant, connected economy } \\
\text { that continuously innovates, } \\
\text { renews and leads markets } \\
\text { Large share of profits are } \\
\text { ploughed back into R\&D, } \\
\text { corporate innovation and new } \\
\text { business models } \\
\text { Above average growth rates } \\
\text { over long term and highly } \\
\text { diversified economy } \\
\text { Effective coordination of } \\
\text { monetary and fiscal policies that } \\
\text { are able to adjust to external } \\
\text { shocks }\end{array}$ \\
\hline $\begin{array}{l}\text { Growth and } \\
\text { infrastructure }\end{array}$ & $\begin{array}{l}\text { Regulations are subject to } \\
\text { change; narrow group of } \\
\text { interests blocks competition } \\
\text { Poor physical infrastructure, } \\
\text { unstable administration and } \\
\text { legal } \\
\text { system }\end{array}$ & $\begin{array}{l}\text { Physical infrastructure } \\
\text { strained by demographic and } \\
\text { economic pressures } \\
\text { Basic regulatory, } \\
\text { administration and legal } \\
\text { systems are in place }\end{array}$ & $\begin{array}{l}\text { Infrastructure continuously } \\
\text { adapts to meet evolving socio- } \\
\text { economic needs } \\
\text { Creative and flexible financial } \\
\text { sector encourages new forms of } \\
\text { financing and broader capital } \\
\text { markets } \\
\text { Government supports and } \\
\text { facilitates business driven } \\
\text { competitiveness }\end{array}$ \\
\hline
\end{tabular}

Figure 1. Event three-stage development model (AT Kearney, 2005). 


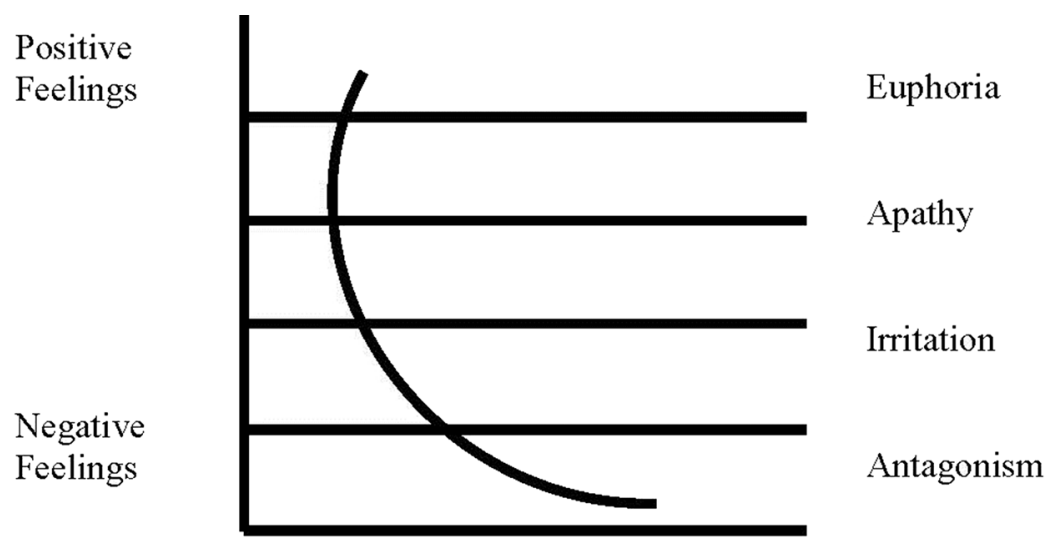

Number of Visitors

Figure 2. Doxey Irridex Index (Reisinger \& Dimanche, 2010).

Potential respondents were individually contacted and provided with a summary of the research objectives and the use of in-depth semistructured interviews yielded rich data. Respondents' names and personal details were withheld from circulation to keep them anonymous.

An interview protocol was designed, and questions were based on social, political, and economic event impacts and recorded for reevaluating and safekeeping purposes. The sample was based on availability, disposition, and location, and a breakdown of those interviewed is in Table 5.

The coding process was ongoing throughout the data collection period. The coding schemes originated from thematic analysis of the transcribed text and deduction of underlying meanings in phrases to provide systematic categories (Hsieh \& Shannon, 2005). To ensure coherence of questions, two pilot interviews were conducted on a prior trip to Zimbabwe. To avoid theming bias, the researcher created

\section{Social Exchange Theory}

Rewards of interaction between community and visitors - costs of interaction $=$ Outcomes (benefits for community)

- Loss of money, prospects, hope and pride

- Unsustainable social benefits
- Recognition

- Financial gain

- Social status

Costs/Negative Outcomes

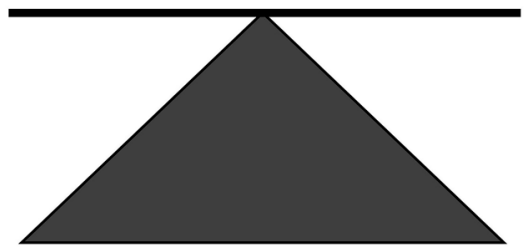

Positive

Outcomes/

Benefits

Figure 3. Social exchange theory (authors, 2014, adapted from Ap, 1992). 
an audit trail, keeping documented verification of the research process. One of the researchers is a Zimbabwean residing in the UK. This was useful for sourcing respondents, but could have resulted in unintentional bias. Nevertheless, Cutcliffe and McKenna (1999) believed if the researcher shares the subject's world, they are well appointed to empathize with the subject's views defying possibly naive expectations.

\section{Findings and Discussion}

For the purpose of this article three themes are presented based on concepts that clearly link to the literature and the objectives of the research. Therefore, three themes with well-defined descriptive data relating the primary and secondary data are presented.

\section{Awareness}

Communities play a huge role in events through the provision of resources and in return events seek to offer benefits as part of a social exchange (Nessel, 2009). Interviewee 3 supported this notion citing, "The community takes events seriously, they see what we do and they benefit often from our services" (Interviewee 3, ZIM). Interviewee 3's response indicates that the local events benefit the community (Jago et al., 2010; Quinn, 2009). On the other hand, Interviewee 13 considers events in the UK to be well established:

\begin{abstract}
We have become really well positioned to host major world events that are upcoming, we are fortunate that we have a major international sporting event every year up till 2019 whether be it the Rowing World Cup, Hockey World Cup, Women's Cricket World Cup. (Interviewee 13, UK)
\end{abstract}

Based on the responses, Zimbabwe and the UK are part of a growing events industry. The data gives evidence of both nations becoming aware of the role of events in their communities, substantiated by Interviewee 7:

Slowly they are aware of events and they are now happier that someone else is doing it for them.

(Interviewee 7, ZIM)

These views are supported by Jurowski and Gursoy (2004) and Jago et al. (2010) who explained that events over the years have gained recognition as a growth stimulator and evidenced by developing nations like China and South Africa.

\section{Economic Influences}

In order to understand what influence events have on the community, it is useful to analyze event trends, such as economic impact. The state of an economy has an effect on events within a

Table 5

Respondent Demographics and Characteristics

\begin{tabular}{lll}
\hline Respondent & \multicolumn{1}{c}{ Job Title } & Country \\
\hline 1 & Event company director & Zimbabwe \\
2 & Events coordinator & Zimbabwe \\
3 & Duty manager and events assistant & Zimbabwe \\
4 & HR training and corporate functions officer & Zimbabwe \\
5 & Events company director & Zimbabwe \\
6 & Part owner of events company & Zimbabwe \\
7 & Events company general manager & Zimbabwe \\
8 & Owner of events company & Zimbabwe \\
9 & Sales and events manager & UK \\
10 & Conference and banqueting manager & UK \\
11 & Events assistant & UK \\
12 & Artistic director & UK \\
13 & Netball Europe competition manager and LOCOG volunteer & UK \\
14 & Wedding planner & UK \\
\hline
\end{tabular}


society. Interviewee 7 articulates the effect that the Zimbabwean economy has had on local events:

We have come out of a very difficult financial season and a lot of companies are now scrambling to advertise their new products hence the need to create awareness and do proper events. (Interviewee 7, ZIM)

Economy is the biggest influencer of event progression ... most event companies are now coming out of a very difficult financial period are finding it hard . . . due to lack of capital. (Interviewee 7, ZIM)

Interviewees 5 and 10 recognize the influence events have especially their economic benefits:

Many people have seen events as a moneymaking opportunity. (Interviewee 5, ZIM)

It is recognized as a major industry due to the money involved in the industry but more importantly due to the money it can generate. (Interviewee 10 , UK)

These interpretations support the discussion in the literature (Gratton \& Preuss, 2008) of the 2002 Commonwealth Games, which benefited Manchester financially and socially, supporting the view that communities will support events that offer them benefits, resulting in a balanced social exchange as discussed in the literature (Jackson, 2008).

Events are a driving force behind social development and economic growth creates opportunities for a sturdy climate to host world-class events (Gibson \& Connell 2011). Interviewee 5 believes that growth requires the country to invest more in its events:

The country's economy is the most important influencer; many young Zimbabweans have studied abroad and are back now ... helping with building skills in the community. For example, The Harare International Festival of Arts (HIFA) is backed by many of these young entrepreneurs and is one of the biggest cultural festivals in the Southern African Development Community (SADC) region receiving attention and support worldwide . . . these projects need money. (Interviewee 5, ZIM)

Developing nations like Zimbabwe should learn from established destinations how to establish an effective event portfolio and funding. The literature advocates (Hede, 2008) setting up event agencies that encourage funding similar to the UK, which has various agencies such as EventBritain.

On the other hand, the UK has gone through an economic crisis and has become cost conscious with funding, more so for start-up event businesses as experienced by Interviewees 11 and 12:

I think money plays a big part, people are a lot more cautious with their money due to the recession so I believe venues have to work a lot harder. . . . Where I worked it was a real push and events was one of the main tools used at the venue to get money. (Interviewee 11, UK)

I tried to fundraise so we could go to more venues but that funding didn't come through. The council didn't want to know . . . the key phrase is start-up businesses; we would love to have some kind of council investment. (Interviewee 12, UK)

Both Zimbabwe and the UK have experienced financial hardships, proving that disruption to economic activity can have an influence on events.

\section{Community Involvement}

Events impact social beliefs, bringing about changes in the quality of life through the fostering of community pride by showcasing local culture and nurturing benefits such as unity and strengthened values as discussed in the literature (Bowdin et al., 2012; Davies, 2011; O’Toole, 2011). This supports Cornelissen and Swart's (2006) opinion that events are facilitators of progress. However, communities are the heart of resources, therefore integral to events:

There is so much potential and our cultural background is a great source of originality that we could use to propel forward. (Interviewee 8, ZIM)

Society has an impact on events . . . the community determines where we host our functions, especially as we have to get licenses ... the communities near the venues are now considered a whole lot more and their opinions have a lot of weight now. So, we would find that ethically, the community would push through an event that they felt was good or beneficial. (Interviewee 11, UK) 
Events enhance quality of life. . . . There is a greater choice of events on offer that caters for all needs and requirements. Events for those who are not involved or interested can be seen as an inconvenience with noise pollution, litter, traffic, safety concerns etc. (Interviewee 10, UK)

Interviewee 10 gives a possible insight into the undesirable side of events thus supporting the Doxey Irridex in that he is of the opinion that events have the potential to cause disruption to a host community.

On the other hand, the social exchange theory (Hardcastle, 2011) built its premise on the principle that the community's opinions and perceptions are determined by the relationships between the community and the guest. Interviewee 3 justifies this:

The society is happy ... we don't charge the community and they can come for free. If the church needs to conduct some seminars, we normally allow them to use our facilities for free as a way of giving back to the community. (Interviewee 3, ZIM)

We source our vegetables from the local community and hire chairs from local vendors. . . . We have partnerships with the local churches, they sometimes provide us with crockery and linen and in exchange we provide them with venues for their events. (Interviewee 3, ZIM)

Gratton and Preuss (2008) discussed that events offer short-term and long-term employment and create opportunities for employment that strengthen relations within the community fostering a balanced social exchange. Consequently, a community that gains positive experiences in their social exchange will remain in the "euphoric stage" of the Doxey Irridex. Jago et al. (2010) discussed that events provide both immediate and long-term employment relief and a lifetime of skills. The following responses give evidence to events relieving unemployment both on a long-term and short-term basis, expressing in the case of Zimbabwe that any employment is better than nothing, but in the UK, there is a preference for jobs that are long term as opposed to temporary prospects:

There have been many small companies that have opened up here in Chiredzi and they supply tables and chairs to clients as well as labor. (Interviewee 1, ZIM)

We work with an employment agency that supplies us with waiters and ushers. They get students to come in. Considering the country has high unemployment; to many people a temporary paid job is better than nothing. (Interviewee 5, ZIM)

Some guys here in Exeter have provided extra jobs that weren't there before and their venue is doing really well and growing. (Interviewee 12, UK)

The industry has developed new employment avenues. The question is the ability to sustain long-term business opportunity and employment. (Interviewee 10, UK)

Let's be honest, once stadiums are built there is no more work but as a nation we did pretty well with job creation during the Olympics . . . there was a scheme being run as well ... young apprentices who wanted to become builders ... . were actually taught on the Olympics Park and learnt invaluable skills. (Interviewee 13, UK)

The findings in conjunction with the discussion from Gratton and Preuss (2008) and Jago et al. (2010) show that the industry provides short-term and long-term relief and skills. These support statistics from the Festival Organizers (2014) reflecting the events sector in the UK, which employs 535,000 people and supports directly and indirectly 25,000 businesses that have contributed $£ 39$ billion to the economy.

Interviewees 5, 10, and 11 discuss their opinions of how events have impacted their communities and the contribution to the local image:

At HIFA, people mingle with a lot of foreigners resulting in exposure and networking . . . another for example is Harare Fashion Week which has made Zimbabwe's events part of the rest of the world. (Interviewee 5, ZIM)

International events such as the Olympics promote Britain at large enabling the country to showcase itself to an international audience as being a proud and diverse nation. (Interviewee 10, UK)

The Olympics was a good initiative as it had the community "feel" and we now have a lot of events ... the Commonwealth games coming up... 
I am now more interested in going to big events . . . it has been a positive impact. Two years on people still refer to the Olympics and things like Wimbledon bringing about national pride. (Interviewee 11 , UK)

The theme fulfils the research aim because it has shown evidence of community involvement as a key event impact defining the resultant social impacts found in both countries. This opens up the local event scene to the opportunity of cultivating homegrown events as illustrated in the responses that reflect on showcasing homegrown events.

\section{Conclusions}

\section{Synthesis of Findings in Response to Research Investigation}

The conclusions arise out of the comparison made across the two countries, as examples of a developed nation and a developing nation. There is still very little research within the events context based around African nations, with the exception of South Africa. This article's contribution is also to hopefully kick start further research in other developing economies worldwide and shift the focus of events literature presently dominated by developed nations.

This research revealed that events are no longer just a preserve for developed nations but also a development tool for developing countries, demonstrated here with Zimbabwe. The research studied the Doxey Irridex and the social exchange theory in an attempt to address event impacts; and they explain the existence of a social exchange within events as well as clarify the importance of balanced interactions. However, the models remain limited. They did not originate from event studies, neither were the theories tested on developing nations during their development stages, thus exposing a gap in current event studies. There is a lack of frameworks designed to assess the extent of event impacts within developing nations.

As a result, the study aimed to build a discussion bringing an understanding to the key impacts affecting developing nations in a bid to design an applicable framework. The aim of this research was to critically analyze the event impacts between a developed and developing country demonstrating different ways event impacts affects different societies. As discussed, events have benefited developed countries through job creation, restoration of community, infrastructure, technology, economic advancement, and social pride. Academics like Hamil, Hassan, and Lusted (2013) challenged this notion with discussed examples of Russia and Greece that experienced event costs that outweighed benefits because of poor organization. However, academics including Abebe, Bolton, Pavelka, and Pierstorff (2013) supported the notion of events immensely benefiting communities.

Though events generate negative impacts, the literature and the findings cite the UK as having benefited from positive events, which is supported by responses recounted in the findings chapter, negating the likes of Hamil et al. (2013), thus proving events can be a tool for development (Abebe et al., 2013). The example of Zimbabwe hosting an effective UNWTO Conference illustrates the potential positive events can have on developing nations, fulfilling the aim of the research by discussing and contributing to the investigation of event impacts in differing societies and identification of a research gap.

The main positive impacts to emerge were in relation to employment, infrastructure, and wellbeing and community pride. Negative impacts included disruption to the community's way of life and redundant infrastructure, demonstrating that events sustain economies, stimulate growth, and encourage investment, but can be economic sinkholes if poorly managed. The events hosted in both nations have caused job creation and encouraged exposure, revealing that events can cause both positive and negative impacts depending on the interaction and social exchanges experienced.

The interviews continuously referred to financial gain or loss as a fundamental event impact, a thought-provoking observation addressing the research agenda. The data pointed towards the economic state of a nation and the resultant benefits of positive events. Social event impacts contribute to the well-being of a community through exposure, employment, infrastructure, and strengthening of community values and pride.

The application of a framework is recommended for better understanding of event impacts helping identify challenges and recognize how to overcome 
them as exemplified through the Doxey Irridex and the social exchange theory. Numerous studies on event impacts have been carried out but unfortunately neglected to conduct comparative studies in developing countries where they experience different social circumstances from developed nations. This has resulted in the design of an event life cycle representing both developed and developing countries in their event transition. This model is an attempt to address the lack of frameworks that measure event impacts in developing nations. The cycle was founded on the literature reviewed and data presented in the findings. The Kwazulu Natal Sport and Recreation Department through AT Kearney (2005) proposed a three-stage development model and was used as a prototype by this study with the modification of certain elements and an introduction of two dimensions that the authors felt were overlooked.

The three-stage model originally comprised of emerging, evolving, and excellent. Whereas here the event life cycle illustrated in Figure 4 covers five stages: starter, replacing emerging; evolving; developing, a new dimension; established, replacing excellent; and regression, a new dimension. The cycle pegs each nation on a success curve of event evolution versus event development, a process that is dependent upon the nation's success in hosting events that are viewed as beneficial. These benefits are determined by the resultant social, political, and economic impacts that influence all states of affairs within that nation.

The cycle assumes that Zimbabwean events are in phase one-evolving. For progress the country needs to maintain economic stability and political agendas that help growth. Phase two assumed to be occupied by the BRICS - emerging nations experiencing a higher level of development. The UK is pegged in phase three representing developed nations with strong political profiles and established economies and successful event portfolio. The cycle assumes that should the UK revert into an economic recession, they stand the chance of falling into phase four representing event regression. Greece is considered to be in phase four based upon their economic and event problems. Therefore, if a nation does not evolve they regress.

Countries like Zimbabwe and the BRICS ought to learn from the UK and study the event impacts that influenced their success in order to emulate their strategy, therefore avoiding disruptive negative impacts. South Africa can use their earned confidence from the FIFA World Cup to bid for future mega-events ensuring steady growth and progression into phase three. Countries in phase two need to be careful not to skip phase three by

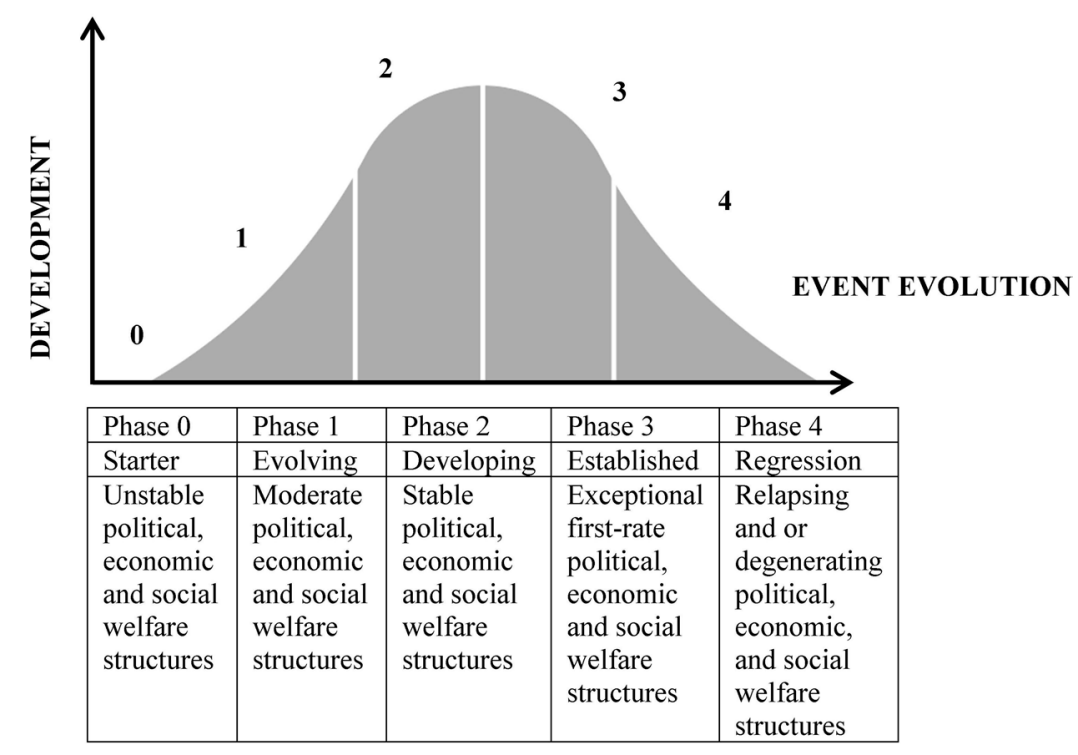

Figure 4. Event life cycle model (authors, 2014). 
going directly into phase four if they do not take heed on how to avoid "white elephants," economic debt, social disparities. For instance, based on Brazil's current event reputation they could skip phase three and go straight to phase four.

\section{References}

Abebe, N., Bolton, M. T., Pavelka, M., \& Pierstorff, M. (2013). Bidding for development: How the Olympic Bid process can accelerate transportation development. New York, NY: Springer Science and Business Media.

Ap, J. (1992). Residents' perception on tourism impacts. Annals of Travel Research, 19(4), 665-690.

AT Kearney. (2005). Building a legacy: Sports mega events should last a lifetime. Retrieved from www.kzndsr.gov. za/Portals/0/GIS/BuildingaLegacy[1].pdf

Beaumont, M., \& Fraser, G. (2014). South Africa considers bid to host 2022 Commonwealth Games. Retrieved from www.bbc.co.uk/sport/commonwealth-games/26117095

Bond, D. (2013). London 2012: UK public says $£ 9 b n$ Olympics worth it. Retrieved from www.bbc.com/sport/ olympics/23434844

Bowdin, G., Allen, J., O’Toole, W., Harris, R., \& McDonnell, I. (2012). Events management (3rd ed.). Oxford, UK: Butterworth-Heinemann.

Brunet, F. (2005). The economic impact of the Barcelona Olympic Games, 1986-2004: Barcelona: The legacy of the games. 1992-2002. Barcelona, Spain: Centre d'Estudis Olimpics UAB.

Corbin, J., \& Strauss, A. (2008). Basics of qualitative research: Techniques and procedures for developing grounded theory. Thousand Oaks, CA: Sage Publications Inc.

Cornelissen, S. (2004). Sport mega-events in Africa: Processes, impacts and prospects. Tourism and Hospitality Planning and Development, 1(1), 39-55.

Cornelissen, S., \& Swart, K. (2006). The 2010 football world cup as a political construct: The challenge of making good on an African promise. Sociological Review, 54, 108-123.

Cutcliffe, J. R., \& McKenna, H. P. (1999). Establishing the credibility of qualitative research findings: The plot thickens. Journal of Advanced Nursing, 30, 374-380.

Davies, C. (2011). Royal wedding: A stylish marriage for William and Kate. Retrieved from https://www.theguard ian.com/uk/2011/apr/29/royal-wedding-william-katemarriage

Doxey, G. V. (1975). A causation theory of visitor-resident irritants: Methodology and research inferences. In Travel and Tourism Research Associations Sixth Annual Conference Proceedings (pp. 195-98), San Diego, CA.

Festival Organizers. (2014). Your events help economic recovery. Retrieved from www.festivalorganisers.org/ news/your-events-help-economic-recovery

Flanders, S. (2013). London 2012 Olympics have boosted UK economy by $£ 9.9 \mathrm{bn}$. Retrieved from http://www.bbc. com/news/uk-23370270
Foley, M., McGillivray, D., \& McPherson, G. (2012). Policy pragmatism: Qatar and the global events circuit. International Journal of Event and Festival Management, 3(1), 101-115.

Gratton, C., \& Preuss, H. (2008) Maximising Olympic impacts by building up legacies. The International Journal of the History of Sport, 25(14), 1922-1938.

Gibson, C., \& Connell, J. (2011). Festival places: Revitalizing rural Australia. Bristol, UK: Channel View.

Hamil, S., Hassan, D., \& Lusted, J. (2013). Managing sport: Social and cultural perspectives. Oxon, UK: Routledge.

Hardcastle, D. A. (2011). Community practice: Theories and skills for social workers. Oxford, UK: Oxford University Press.

Hede, A. (2008). Examining the relationship between event owners and host destinations. Retrieved from http:// www.academia.edu/1587134/EXAMINING_THE_ RELATIONSHIP_BETWEEN_EVENT_OWNERS_ AND_HOST_DESTINATIONS

Hetherington, P. (2012). What the London Olympics could learn from the Manchester Games. Retrieved from https:// www.theguardian.com/society/2012/jul/24/londonolympics-learn-manchester-games

HM Government. (2013). Inspired by 2012: The legacy from the London 2012 Olympic and Paralympic Games. Ajoint UK Government and Mayor of London report. Retrieved from https://www.gov.uk/government/uploads/system/ uploads/attachment_data/file/224148/2901179_Olympic Legacy_acc.pdf

Hochstetler, K. (2012). Brazil as an emerging environmental donor. Retrieved from https://www.cigionline.org/sites/ default/files/no21_0.pdf

Horne, J. (2010). Building BRICs by building stadiums: Preliminary reflections on recent and future sports megaevents in four emerging economies. Retrieved from www.eldis.org/document/A68279

Hsieh, H. F., \& Shannon, S. E. (2005). Three approaches to qualitative content analysis. Qualitative Health Research, 15(9), 1277-1288.

Jackson, L. (2008). Residents' perceptions of the impacts of special event tourism. Journal of place management and development, 1(3), 240-255. Retrieved from https:// www.deepdyve.com/lp/emerald-publishing/residentsperceptions-of-the-impacts-of-special-event-tourismKkmaGxhf34

Jago, L., \& Dwyer, L. (2006). Economic evaluation of special events: A practitioner's guide (1st ed.). Altona, Victoria: Common Ground Publishing Pty Ltd.

Jago, L., Dwyer, L., Lipman, G., van Lill, D., \& Vorser, S. (2010). Optimising the potential of mega-events: An overview. International Journal of Event and Festival Management, 1(3), 220-237.

Joy, O. (2013). Building on "BRICS": The next emerging economies. Retrieved from http://edition.cnn.com/2013/ 03/27/business/brics-civets-emerging-markets/index.html

Jurowski, C., \& Gursoy, D. (2004). Distance effects on residents' attitudes toward tourism. Annals of Tourism Research, 31(2), 296-312. 
Kahane, L. H., \& Shmanske, S. (2012). The Oxford handbook of sports economics (Vol. 1). Oxford, UK: Oxford University Press.

Kirst-Ashman, K. (2013). Brooks/Cole empowerment series: Human behavior in the macro social environment (4th ed.). Belmont, CA: Cengage Learning.

Latkova, P. (2008). An examination of factors predicting residents' support for tourism development. Ann Arbor, MI: Proquest LLC.

MacIntosh, E, W., \& Nicol, L. (2012). Athletes' event experiences of the XIX Commonwealth Games in Delhi, India. International Journal of Event and Festival Management, 3(1), 12-29.

Monterrubio Cordero, J. C. (2008). Residents perception of tourism: A critical theoretical and methodological review. Ciencia Ergo Sum, 15(1), 35-44.

Moore, T. (2012). Economic impact of events and festivals on local regions. Retrieved from http://go-group.org/wpcontent/uploads/2012/05/Economic-impact-of-majorevents-on-local-regions2-Budapest-April-2012.pdf

Mudzaki, M. (2014). Zim named 2014 world best tourist destination. Retrieved from http://www.herald.co.zw/ zim-named-2014-world-best-tourist-destination/

Mukwereza, L. (2013). Chinese and Brazilian cooperation with African Agriculture: The case of Zimbabwe. Working Paper CBAA 48, Future Agricultures Consortium. Retrieved from www.eldis.org/document/A64415

Murray, P. (2013). Zimbabwe (2nd ed.). Bucks, UK: Bradt Travel Guides Ltd.

Murphy, P, E., \& Murphy, A, E. (2004). Strategic management for tourism communities: Bridging the gaps. Clevedon, UK: Channel View Publications.

Nash, M. (2013). London Olympic Park: What became of the 2012 venues? Retrieved from http://metro.co.uk/ 2013/07/28/london-olympic-park-what-became-of-the2012-venues-3901657/

Nessel, J. (2009). Festival city: A case study of successful festivals. Retrieved from https://www.fairsandfestivals.net/ articles/view/festival-city-a-case-study-of-successfulfestivals/500

Nye, J. (2004). Soft power: The means to success in world politics. New York, NY: Public Affairs.

Olympic.org. (2012). London 2012. Retrieved from https:// www.olympic.org/london-2012

O'Toole, W. (2011). Events feasibility and development: From strategy to operations. Langford, UK: Elsevier.

Pomfret, R., Wilson, J. K., \& Lobmayr, B. (2009). Bidding for sport mega events. Retrieved from https://economics. adelaide.edu.au/research/papers/doc/wp2009-30.pdf

Preuss, H., \& Alfs, C. (2011). Signaling through the 2008 Beijing Olympics-using mega sport events to change the perception and image of the host. European Sport Management Quarterly, 11(1), 55-71.

Provost, C. (2011). The rebirth of Russian foreign aid. Retrieved from https://www.theguardian.com/globaldevelopment/2011/may/25/russia-foreign-aid-reportinfluence-image
Quinn, B. (2009). Festivals, events and tourism. In T. Jamal \& M. Robinson (Eds.), The SAGE handbook of tourism studies (pp. 483-503). London, UK: Sage.

Reisinger, Y., \& Dimanche, F. (2010). International tourism. Oxford, UK: Routledge.

Saayman, M. (2012). Introduction to sports tourism and event management. South Africa: Sun Media Metro.

Saayman, M., \& Saayman, A. (2012). Determinants of spending: An evaluation of three major sporting events. International Journal of Tourism Research, 14, 124-138.

Sandelowski, M. (2000). Focus on research methods: Whatever happened to qualitative description? Research in Nursing and Health, 23, 334-340.

Shipway, R., \& Fyall, A. (2012). International sports events: Impacts, experiences and identities. Oxon, UK: Routledge.

Sloman, J. (2006). Economics. Bristol, UK: Financial Times Press.

Smith, A., \& Fox, T. (2007). From “event-led” to “eventthemed" regeneration: The 2002 Commonwealth Games Legacy Programme. Urban Studies, 44, 1125-1143.

Smith, H. (2012). Athens 2004 Olympics: What happened after the athletes went home? Retrieved from https:// www.theguardian.com/sport/2012/may/09/athens-2004olympics-athletes-home

Swart, K., \& Bob, U. (2007) Listening to community voices: Athlone and Green Point residents' views on the location of the 2010 FIFA World Cup Stadium in Cape Town. 7th International Hamburg Symposium "Sport and Economics" on the economics of top performance in international sports, Hamburg Chamber of Commerce, Hamburg, Germany.

Swart, K., \& Bob, U. (2012). Reflections on developing the 2010 FIFA World Cup ${ }^{\mathrm{TM}}$ research agenda. In International handbook on the economics of mega sporting events. Cheltenham, UK: Edward Elgar Publishing. Retrieved from https://www.elgaronline.com/view/978 0857930262.00033.xml

Trauer, B., \& Ryan, C. (2005). Destination image, romance and place experience-an application of intimacy theory in tourism. Tourism Management, 26(4), 481-491.

United Nations. (2010). Africa's cooperation with new and emerging development partners: Options for Africa's development. Retrieved from http://www.un.org/en/ africa/osaa/pdf/pubs/2010emergingeconomies.pdf

Wearden, G. (2014). Eurozone growth misses forecasts as France stagnates and Italy contracts-as it happened. Retrieved from https://www.theguardian.com/business/ 2014/may/15/eurozone-gdp-french-economy-stagnatesgermany-growth-live

Yaffa, J. (2014). The waste and corruption of Vladimir Putin's 2014 Winter Olympics. Retrieved from https://www.bloom berg.com/news/articles/2014-01-02/the-2014-winterolympics-in-sochi-cost-51-billion

Zimbabwe Tourism. (2014). Zimbabwe events, things to do and festivals 2014/2015. Retrieved from http://www. world-guides.com/africa/southern-africa/zimbabwe/ zimbabwe_events.html 